\title{
Dominant and Subdominant Types of Nature Resources in Ukraine: Regional Analysis
}

\author{
Valeriy Rudenko, Stepan Rudenko, Myroslav Zayachuk, Zhanna Buchko, Valentuna Hudikovska, \\ Myroslava Lapushniak
}

Chernivtsi National University, Chernivtsi, Ukraine.

Email: rudenko valery@ukr.net, rudenkostepan@ukr.net, zayachykmyroslav@ukr.net, zhanna/buchko@gmail.com, valentina hudikovsha@ukr.net

Received December $6^{\text {th }}, 2013$; revised January $11^{\text {th }}, 2014$; accepted January $29^{\text {th }}, 2014$

Copyright (C 2014 Valeriy Rudenko et al. This is an open access article distributed under the Creative Commons Attribution License, which permits unrestricted use, distribution, and reproduction in any medium, provided the original work is properly cited. In accordance of the Creative Commons Attribution License all Copyrights (C) 2014 are reserved for SCIRP and the owner of the intellectual property Valeriy Rudenko et al. All Copyright (C) 2014 are guarded by law and by SCIRP as a guardian.

\section{ABSTRACT}

Geographic specificities of allocation of basic (dominant) and second significant (subdo-minant) types of nature resources of Ukraine are disclosed in the aspect of 278 Ukrainian natural (physic-geographic) rayon. Major territorial combinations of nature resources formed in the state's natural regions are exposed.

\section{KEYWORDS}

\section{Ukraine; Nature Resources; Dominant and Subdominant Types of Nature Resources; Resources Mapping}

\section{Introduction}

Balanced development of nature use in this or that region undoubtedly presupposes, on the one hand, its orientation towards key (basic) types of nature resources, and, on the other, towards their analysis and estimation from the point of view of rather natural than administrative units. Such (no article) approach allows for provision of economic (non-exhaustive) use of basic nature wealth of the area within the limits of naturally formed nature-resource rayon.

This trend is substantiated in the works by W. Marsh, I. M. Ir. Grossa, [1], C. C. Williams, A. S. Millington [2], N. Lee, C. George [3], etc.

\section{Aim and Tasks of Investigation}

The present work aims at territorial analysis of basic (dominant) and second significant (subdominant) types of nature resources in Ukraine in the aspect of its 278 natural (physic-geo-graphic) rayon. Said analysis presupposes wide use of cartographic method to visualize the results of cost estimation made for nature-resource potential (NRP) of Ukrainian natural regions.

\section{Research Methods and Areas}

Materials of cost estimation of state's NRP published in
[4,5] were the basis for geographical analysis of the allotment of basic and second significant types of Ukrainian nature resources.

NRR of the territory that includes mineral, water, land, forest, fauna and natural recreational resources is exceptionally inertial and relatively stable with regard to its quantitative and qualitative development. Thus, natural reassessment of major portion of nature resources throughout the country is carried out no frequently than every 10 - 20 years. This is also true for ecological-economic assessments of the country's NRP components. For instance, the last economic appraisal of all agricultural lands of Ukraine dates back to 1987-1988. Similar situation is with mineral, water and forest resources. On the one hand, vast financial resources are required for such labor-consuming broad-scale operation; on the other, considering the aforementioned inertia of NRP, there is no imperative need for such measures (for instance, the country's annual mean volume of water resources is virtually identical for both 1980-1985 and 2000-2005).

As to present-day situation, all the aforesaid justifies Ukrainian geographers engaged in resource studies to sharply focus on the problem of indexation of cadastre assessments of natural resources as made was in the late 1980s-1990s. Our previous investigations into NRP for 
1980-1992 were comprehensively discussed in [6]. Thus, the value of the country's total natural-resource potential on a yearly basis was estimated to amount to 53.95 billion rubles. In particular, the mineral potential was represented by Ukrainian major groups of mineral deposits: fuel and energy feedstock, metallic minerals, non-metallic minerals for ferrous industry, mining chemical feedstock, mineral building materials. Mineral potential estimation bases on deposit stock of only A + B + C1 categories.

The potential of water resources is estimated proceeding from economic effect gained from water use in major Ukrainian water-consuming branches: irrigated agriculture, agricultural and industrial production, hydropower industry. The potential is characterized by the average annual local runoff as well as by the flow of Byelorussian and Russian rivers (with no consideration of the waters of the Danube River).

The potential of Ukrainian land resources is estimated proceeding from the results of aggregate economic estimation of all agricultural lands carried out within a unified system of land cadastre.

Calculation of average annual productivity of forest resources is based on the primary materials of forest engineering and forest regional records. Wood resources potential is represented as the product of annual increment of major forest-forming species within the site condition types and their area and cadastre price of $1 \mathrm{~m}^{3}$ of non-specific wood with introduction of quality coefficients.

The potential of natural recreation resources is defined through the money value of free time [6].

Now it is important to make clear how the NRP is measured in value terms in prices of 2006-2010 in the UAH and US dollar equivalent; what the country's current nature-resource opportunities are on the world market and what prospects for further development of nature management sectors in subsequent years are.

To our opinion, assessment must base on the central, key sector of Ukrainian nature-resource complex, that is, on land resources representing the main element of national wealth. Among the multitude of scientific approaches to determining the potential of agricultural lands, publication by I. R. Yukhnovs'kyi and G. M. Loboda [6] deserves particular attention. The authors' basic idea implies that "the natural yielding capacity of Ukrainian lands must be used, i.e. the one achieved by adhering to crop rotation with only mechanical soil cultivation applying no fertilization" and serves as the basis for normalized assessment [7].

According to the data available with the Soil Science and Agro-Chemistry Institute of the Ukrainian Academy of Sciences, the grains average natural yield capacity in Ukraine amounts to $26 \mathrm{dt} / \mathrm{ha}$, which is a serious evidence of the country's advantages in the world. At the same time, taking into account that the values of average yield capacity in 1995-2000 were lower than those of natural capacity, I. R. Yukhnovskyy and G. M. Loboda suggested that, temporarily and until the yield natural capacity is rehabilitated, the average cost standards be calculated at a level of $21 \mathrm{dt} / \mathrm{ha}$. The authors therewith insisted that the value of land tax would not depend on agricultural producer's real income, but be calculated proceeding from normative income, i.e. the one gained in each particular area provided that a certain economy management standard was kept to. This principle would compel agricultural producer to improve the land use practices since a fixed tax would be required to be paid regardless of the achieved economic management results.

As calculated by scientists of the Soil Science and Agro-Chemistry Institute of the Ukrainian Academy of Sciences, average standard cost price of grain in Ukraine amounts to $\$ 62$ per ton, while its costto $\$ 97$. Hence, the average standard profit will amount to $\$ 73.5 /$ ha. Having taken these as the basis, and with the bank interest rate of $23.5 \%$ for deposits to natural persons and with the absolute land rent amounting to $\$ 16 /$ ha, I. R. Yukhnovskyy and G. M. Loboda obtained the normative starting price of arable land to be $\$ 381 / \mathrm{ha}$. At the same time, "considering high interest rate for bank deposits, the average normative land's price in Ukraine in present-day conditions is nearly 10 times lower than its real cost”. That is, the present-day price of arable land is $\$ 3810 / \mathrm{ha}$.

Having considered that the value of 1 ha perennial crop lands is three times higher, and natural forage nearly two times lower than the arable land price, we'll get the normative starting price for the potential of all agricultural lands in the country to be $\$ 159.3$ milliard.

Here we must remember that we speak about the socalled capitalized estimation of the potential of agricultural lands. With Ukrainian economics' average normative coefficient of capital investments' efficiency of 0.15 , the value of land potential in this country in yearly proportion will amount to $\$ 23.9$ milliard.

It should be noted that in 1990s we performed calculations of the value of the country's starting nature-resource potential in USD equivalent and found the annual average potential of the country's agricultural lands to be $\$ 24.18$ milliard. And, as it is evident today, the land price according to I. R. Yukhnovskyy and G. M. Loboda practically coincides with our findings. In this case, the scale of comparability of the potential of the country's most important nature resource seems to be very important, since it is the one that allows (to a certain extent) for application of corresponding conversion coefficients so that we could transform Ukrainian NRP value in nature resource prices of 1990s into the same of present day nature use development. We believe that the USD/UAH 
exchange rate of 1:6.3 could become the coefficient that would help converse nature resource cadastre prices of 1990s into those of present day. According to suggested method, the integral (total) Ukrainian NRP that includes mineral, water, land, forest, fauna and natural recreational resources, amounts to UAH 338,392 milliard, or USD 53, 953 in 2006-2010 prices.

\section{Results}

The table and the figures hereunder represent results of NRP estimation in the aspect of Ukrainian natural regions on the level of physic-geographic countries and zones (Table 1) and physic-geographical rayon (Figures 1 and 2).

As seen from the map scheme (Figure 1), land potential represents basic nature resource in the majority of Ukrainian physic-geographic rayon (in 211 of 278 rayon, or almost in $76 \%$ of the whole number). Land potential's positions are most significant in Forest-Steppe, Mixed Forest and Deciduous Forest Zones of Ukraine.

Second place is taken by mineral potential. It is first (dominant) resource in 30 physic-geo-graphic regions of Ukraine. Its significance is most vivid in North-Steppe Sub-Zone of the Steppe Zone, Kerch Hill-Ridge Oblast, and in four rayon of Northern Prykarpattia.

Ukrainian water resources are dominating in 20 rayon with Ukrainian Carpathians as basic rayon of allotment.

Natural recreational potential is a basic resource in 16 physic-geographic rayon of Ukraine (nearly 6\% of the rayon total number). Crimean Mountains and rayon of Zakarpattia take here leading positions.

Much more mosaic is geographical situation with second significant (subdominant) type of nature resource allotted by natural rayon of Ukraine (see Figure 2).

Water potential as second-significant resource dominates in the majority of rayon. Its significance is espe- cially notable in Mixed Forest, Deciduous Forest and Forest-Steppe Zones, Mid-Steppe and Southern Steppe Sub-Zones of Steppe Zone (at the expense of the Dnieper irrigation channels).

Great spaces of North Steppe Sub-Zone of Steppe Zone are clear evidence of land's potential subdominant role. The same is with Crimean Mountains and Crimean Steppe Kray.

On the opposite, forest potential is second-significant type of nature resources in Outer-Carpathian, InterstreamVerkhovyna Oblasts of Ukrainian Carpathians, and Oblasts of Volyn Polissia.

It is interesting to note that natural recreational potential's subdominant role makes itself evident within zones of influence of big cities and cities-millionaires where the so-called day-off trips are made.

\section{Conclusions}

1) As witnessed by corresponding materials of quantitative and cartographic estimation, each physic-geographic region of Ukraine represents specific and its own NRP structure that proves a complex interaction of natural and social-economic factors.

2) The territory of East-European Plain that characterizes $9 / 10$ of the Ukrainian integral NRP is dominated by land and mineral resources which share $46 \%$ and $30 \%$ correspondingly in the potential structure.

3) Land-water-recreational, land-water-mineral, landmineral-water and land-recreational-water resources represent dominating territorial combinations of nature resources in newly separated Deciduous Forest Zone of Ukraine, while land-water-recreational combination dominates in Forest-Steppe Zone.

4) Crimean Mountains are characterized by basic elements of recreational-land-mineral type of nature resources while Ukrainian Carpathians possess basic com-

Table 1. Results of NRP estimation in the aspect of Ukrainian natural regions on the level of physic-geographic countries and zones.

\begin{tabular}{|c|c|c|c|c|c|c|c|}
\hline \multirow[b]{2}{*}{ Natural Region } & \multicolumn{7}{|c|}{ Value of the Potential (UAH milliard/USD milliard) } \\
\hline & Mineral & Water & Land & Forest & Fauna & $\begin{array}{c}\text { Natural } \\
\text { Recreational }\end{array}$ & Integral \\
\hline Ukraine & $95.615 / 15.245$ & $44.248 / 7.055$ & $150.192 / 23.946$ & $14.111 / 2.250$ & $1.603 / 0.256$ & $32.623 / 5.201$ & 338.392/53.953 \\
\hline East-European Plain & 93.019/14.831 & $37.137 / 5.921$ & $143.381 / 22.86$ & $9.822 / 1.566$ & $1.573 / 0.251$ & $25.382 / 4.046$ & $310.314 / 49.475$ \\
\hline Mixed Forest Zone & $14.65 / 0.234$ & $6.333 / 1.01$ & $15.649 / 2.495$ & $4.315 / 0.688$ & $0.196 / 0.031$ & $3.406 / 0.543$ & $31.364 / 5.001$ \\
\hline $\begin{array}{c}\text { Deciduous Forest } \\
\text { Zone }\end{array}$ & 2006/0.320 & $4.101 / 0.654$ & $17.683 / 2.819$ & $1.425 / 0.227$ & $0.100 / 0.016$ & $2.511 / 0.400$ & $27.826 / 4.436$ \\
\hline Forest-Steppe Zone & $5.284 / 0.842$ & $8.949 / 1.427$ & $52.118 / 8.31$ & $2.915 / 0.465$ & $0.585 / 0.093$ & $6.534 / 1.042$ & $76.385 / 12.179$ \\
\hline Steppe Zone & $84.264 / 13.435$ & $17.754 / 2.831$ & 57.931/9.236 & $1.167 / 0.186$ & $0.692 / 0.11$ & $12.907 / 2.058$ & $174.715 / 27.856$ \\
\hline Crimean Mountains & $0.613 / 0.098$ & $0.512 / 0.082$ & $2.181 / 0.348$ & $0.305 / 0.049$ & $0.010 / 0.002$ & $2.671 / 0.426$ & $6.292 / 1.005$ \\
\hline Ukrainian Carpathians & 1.983/0.316 & $6.599 / 1.052$ & $4.630 / 0.738$ & $3.984 / 0.635$ & $0.020 / 0.003$ & $4.570 / 0.729$ & 21.786/3.473 \\
\hline
\end{tabular}




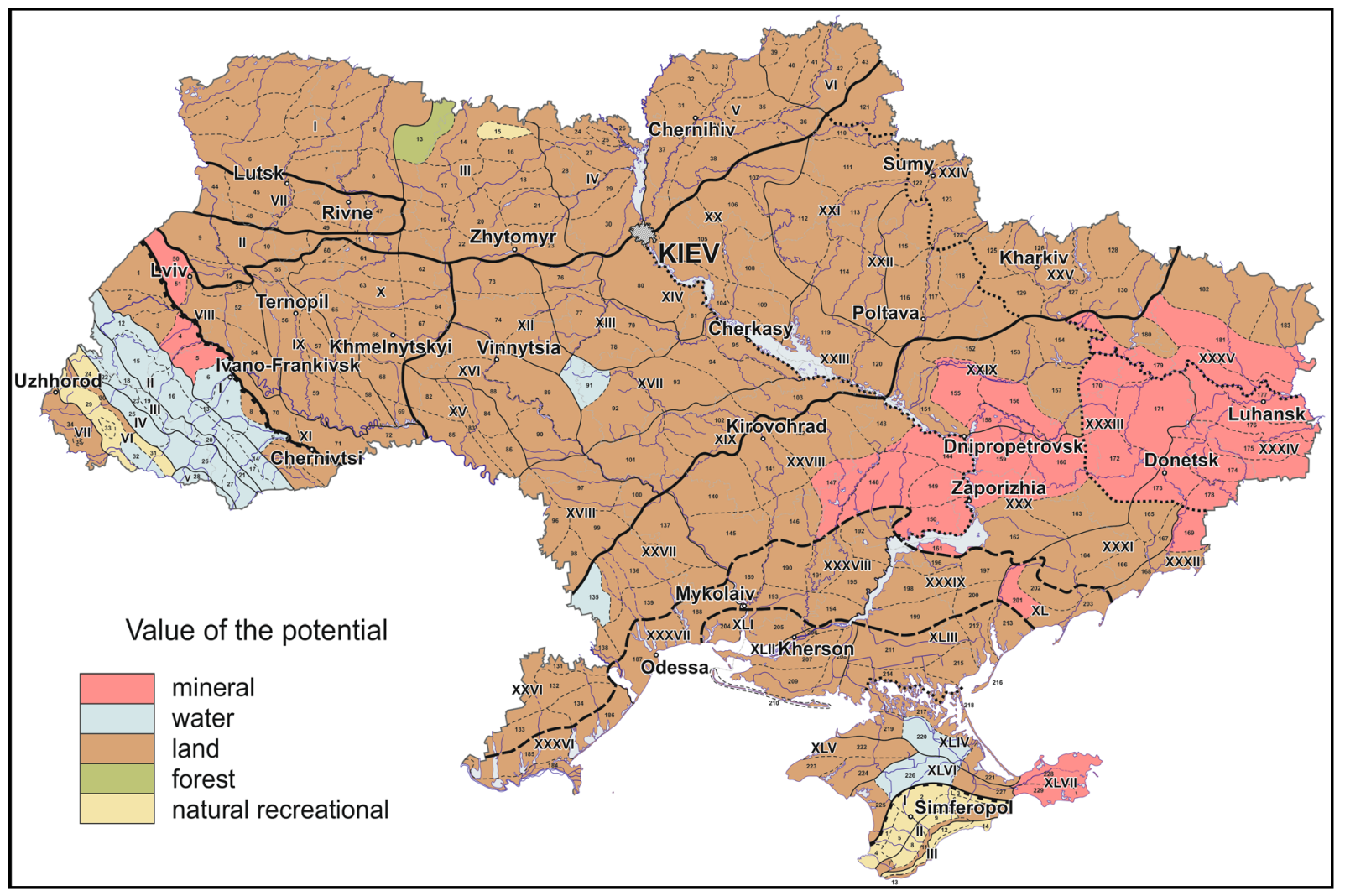

Figure 1. Dominant (basic) nature resource in NRP structure of Ukrainian physic-geographical rayons.

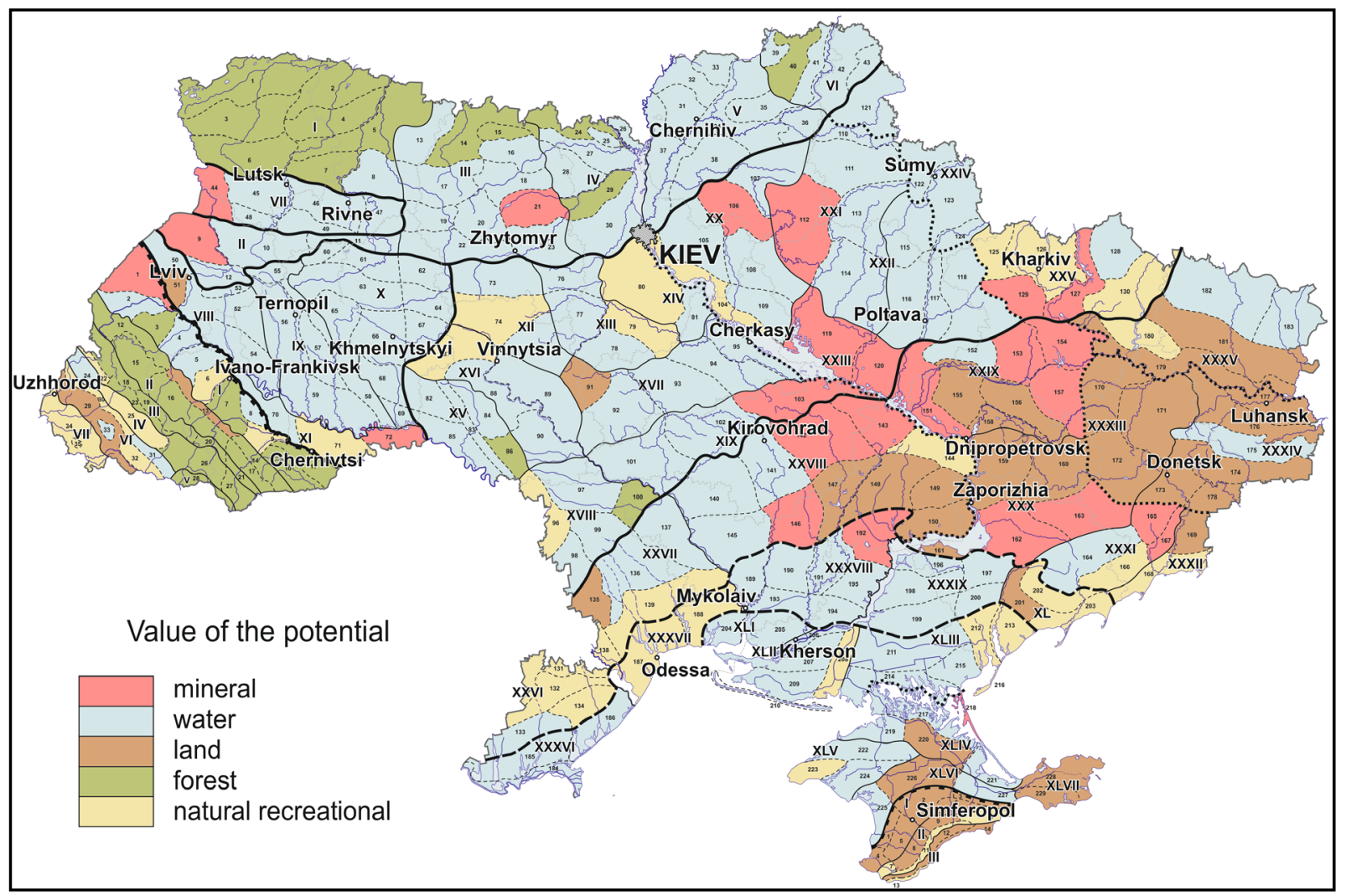

Figure 2. Subdominant (second significant) nature resource in NRP structure of Ukrainian physic-geographical rayons. 
ponents of water-land-recreational nature-resource complex.

\section{REFERENCES}

[1] W. Marsh, “Environmental Geography,” Wiley, New York, 2002, 440 p.

[2] C. C. Williams, "The Diverse und Contested Meanings of Sustainable Development," The Geographical Journal, No. 170, 2004, pp. 99-104.

[3] N. Lee, "Environmental Assessment in Developing and Transitional Countries,” Wiley, New York, 2002, 290 p.

[4] V. P. Rudenko and S. V. Rudenko, "Revaluation of Nature-Resource Potential of Ukraine," Geography and Na- tural Resources, Vol. 32, No. 1, 2011, pp. 95-97.

[5] V. Rudenko, M. Zayachuk and M. Palamaryuk, "NatureResource Potential of the Carpathian Region of Ukraine and Specificities of Its Use by Farming Enterprises," Natural-Resources, Vol. 4, No. 3, 2013, pp. 257-262. http://dx.doi.org/10.4236/nr.2013.43032

[6] V. P. Rudenko, "Geography of Ukrainian Nature-Resource Potential,” Chernivtsi Yuriy Fedkovych National University, Chernivtsi, 2010, 552 p.

[7] I. Yukhnovsky and G. Loboda, "Land Price,” Ukrainian Government's Courier, No. 105, 2002, p. 7. 